\title{
Surgical sponge associated with platelets rich plasma in skin mesh grafts and layer in rabbits (Oryctolagus cuniculus)
}

\author{
[Esponja cirúrgica associada com plasma rico em plaquetas em enxertos cutâneos em \\ malha e camada em coelhos (Oryctolagus cuniculus)] \\ J.M. Pazzini ${ }^{1}$,E.L. Serafim ${ }^{2}$, R.R.A. Uscategui ${ }^{1}$, V.T. Almeida ${ }^{1}$, C.A.C. Oliva ${ }^{1}$, \\ F. Gärtner ${ }^{3}$, I. Amorim ${ }^{3}$, F. Faria ${ }^{3}$, A. Rêma ${ }^{3}$, N.P. Reis Filho ${ }^{1}$, M.G.P.A. Ferreira ${ }^{1}$, \\ A.C. Silva ${ }^{1}$, R.R. Huppes ${ }^{4}$, P.C. Moraes $^{1}$, J.A. Oliveira ${ }^{1}$, A.B. Nardi ${ }^{1}$ \\ ${ }^{1}$ Universidade Estadual Paulista - Jaboticabal, SP \\ ${ }^{2}$ Veterinário autônomo - Irapuã, SP \\ ${ }^{3}$ Universidade do Porto - Porto, Portugal \\ ${ }^{4}$ Centro Universitário de Maringá - Maringá, PR
}

\begin{abstract}
The aim of this study was to evaluate of the efficacy of PRP employment associated with surgical sponges to improve the integration of the graft in the recipient bed. It was held at the Veterinary Hospital UNESP, Campus of Jaboticabal - SP, a study of 64 rabbits, divided into eight groups with eight animals. The groups were divided in control with saline solution $0,9 \%$, control with PRP both without the sponge, surgical sponge with PRP, surgical sponge without PRP, and were used mesh and layer grafts in the respective groups. The data were submitted to statistical analysis (paired t-test, Kruskal-Wallis test, with subsequent use of the multiple comparison tests of Dunn, analysis of variance $(\mathrm{F})$ test, Tukey test, $\mathrm{P}<0.05$ ). Edema and exudate with 3 and 3 and 7 days $(\mathrm{P}=0,03$ e $\mathrm{P}=0,0049)$; coloring on the 14th day $(\mathrm{P}=0,0001)$; cosmetic appearance on the 7 th and 14 th day $(\mathrm{P}=0,0026$ and $\mathrm{P}=0,0001)$; mononuclear cells $(\mathrm{P}=0,01)$ and polymorphonuclear $(\mathrm{P}=0,01)$; fibroblast proliferation $(\mathrm{P}=0,01)$; collagenous $(\mathrm{P}=0,05)$; hemorrhage ( $\mathrm{P}-007)$; necrosis and re-epithelialization $(\mathrm{P}=$ $0,2928$ and $\mathrm{P}=0,1)$. We concluded that the use of Platelet Rich Plasma Gel on skin grafts associated with a sponge as a compressive dressing promote the skin graft survival without a previous granulation tissue.
\end{abstract}

Keywords: rabbit, skin grafts, compressive dressing, angiogenesis, PRP

\section{RESUMO}

O objetivo deste estudo foi avaliar a eficácia do PRP associado com esponjas cirúrgicas na integração do enxerto ao leito receptor. Realizou-se, no Hospital Veterinário da Unesp, Jaboticabal, SP, um estudo com 64 coelhos, separados em oito grupos, com oito animais. Os grupos foram: Gprpc (PRP, sem esponja cirúrgica, enxerto camada), Gprpce (PRP, esponja cirúrgica, enxerto camada), Gcc (solução fisiológica 0,9\%, sem esponja cirúrgica, enxerto camada), Gcce (solução fisiológica 0,9\%, esponjas cirúrgicas, enxerto camada), Gprpm (PRP, sem esponja cirúrgica, enxerto malha), Gprpme (PRP, esponja cirúrgica, enxerto malha), Gcm (solução fisiológica 0,9\%, sem esponja cirúrgica, enxerto malha) e Gcce (solução fisiológica 0,9\%, esponjas cirúrgicas, malha). Os dados foram analisados pelo teste t emparelhado, Kruskal-Wallis, análise de variância, e teste de Tukey $(\mathrm{P}<0,05)$. Edema e exsudato presente com três e sete dias $(P=0,03$ e $P=0,0049)$; coloração cianótica no $14^{\circ}$ dia $(P=0,0001)$; aspecto cosmético bom no sétimo e no $14^{\circ}$ dia $(P=0,00026$ e $P=0,0001) ;$ presença de células mononucleares $(P=0,01)$ e polimorfonucleares $(P=0,01)$; proliferação de fibroblastos discreta $(P=0,01)$; colagenização intensa $(P=0,05)$; hemorragia discreta $(P=0,007)$; ausência de diferença significativa em necrose $e$ reepitelização $(P=0,2928$ e $P=0,1)$. Conclui-se que o emprego do PRP gel em enxertos cutâneos associando esponjas cirúrgicas como curativo compressivo favorece sua integração ao leito receptor sem a presença prévia de tecido de granulação.

Palavras-chave: coelho, enxertos cutâneos, curativo compressivo, angiogênese, PRP

Recebido em 31 de outubro de 2016

Aceito em 31 de janeiro de 2018

E-mail: josipazzini@hotmail.com 


\section{INTRODUCTION}

Skin grafts are a segment of the epidermis and dermis that is completely removed from the donor region and transferred to the receptor site without the presence of vascular pedicle (Pazzini et al., 2015). They are used to repair defects with a large loss of continuity of the integument, or lack of skin elasticity, which compromise healing (Castro et al., 2015).

The grafts don't have vascular pedicle, so compressive dressing is recommended to optimize the contact of the graft to the wound bed and allow adequate angiogenesis. In the range of three to five days begin communications vascular in the transplanted skin, so the pressure dressing reduces the possibility of dislocations that affect this communication. Furthermore, they reduced occurrence of seroma and bruise, events that frequently lead to the loss of vitality and, consequently, to graft failure (Pavletic, 2010).

However, the successful healing of the grafts depends on proper angiogenesis (Pazzini et al., 2015). Thus, the problems encountered related to neovascularization in surgical procedures are the subject of many studies, and the platelet-rich plasma (PRP) is a substance that has been researched to have factors that stimulate angiogenesis and aid in tissue repair (Santos, 2007). Studies indicate that this product can stimulate various processes involved in tissue recovery mainly epithelialization and angiogenesis (Pazzini et al., 2016a).

The purpose of this study was to evaluate the effectiveness of employment platelet-rich plasma gel (PRP) in full-thickness skin grafts in the layer and mesh to used in rabbits (Oryctolagus cuniculus) associating postoperative surgical sponges as compressive dressing. The possibility of PRP that surgical sponges improve the integration of the graft to receptor site without a previous presence of granulation tissue was evaluated. Also, evaluated was the local angiogenesis where the procedure was performed and reduction of occurrence of necrosis.

\section{MATERIAL AND METHODS}

Surgical procedures of this study were performed at the Veterinary Hospital of the Faculty of
Agricultural and Veterinary Sciences (FCAV/UNESP), Jaboticabal Campus. The material to histological analysis were made in Veterinary Pathology Laboratory of the University of Porto, Portugal. This study was approved by the Ethics Committee on Animal Use (CEUA) of the Universidade Estadual Paulista (UNESP), Jaboticabal Campus (Protocol number: 11767/14).

The experimental model used to perform the reconstructive surgery was the rabbit (Oryctolagus cuniculus). 64 rabbits White New Zealand were used, with 60 days of age, females and an average weight of $3 \mathrm{~kg}$ from producer specialized. The animals were divided into eight groups of eight animals each. The groups were Gprpl (PRP, without surgical sponge, layer graft), Gprpls (PRP. with surgical sponge, layer graft), Gcl (control, saline solution 0,9\%, without surgical sponge, layer graft), Gcls (control, saline solution $0.9 \%$, with surgical sponges, layer graft), Gprpm (PRP, without surgical sponge, mesh graft) Gprpms (PRP, with surgical sponge, mesh graft), Gcm (control, saline solution $0.9 \%$, without surgical sponge, mesh graft), Gcms (saline solution $0.9 \%$, with surgical sponges, mesh graft). The anesthetic protocol which the animals were submitted consisted of midazolam dose of $0.5 \mathrm{mg} / \mathrm{kg}$ intramuscular (IM) and tramadol hydrochloride at a dose of $5 \mathrm{mg} / \mathrm{kg}$ by the same way. After the anesthetic, blood samples were collected from the 64 rabbits and were submitted through the sealed face mask with isoflurane in 3\% dose diluted in $100 \%$ oxygen, to produce surgical anesthesia.

The preparation of platelet-rich plasma was conducted as recommended by the literature (Pazzini et al., 2016b). The surgical procedure for reconstruction using graft was performed in a single moment, replacing the granulation tissue by platelet-rich plasma. For the realization of the dermal-epidermal wound and marking of the skin segment to be removed in the left carpal region, was used a surgical pen and sterile ruler to create a lesion of $16 \mathrm{~cm}^{2}$, The lesion was made according to the following dimensions: $1 \mathrm{~cm}$ above the metacarpal, and in the sequence a square $4 \mathrm{~cm}$ long by $4 \mathrm{~cm}$ wide was drawn. After performing the carpus injury, the skin graft with $9 \mathrm{~cm}^{2}$ was done in the left lateral chest, with skin incision square format with depth limits determined by the anatomical references 
described in the literature (Pazzini et al., 2015). Some slits were cut in mesh grafts, and the layer graft only in the waste cleaning. Subsequently promoted to hemostasis of local vessels in the recipient bed and started the implementation of the graft. Sutures separate simple pattern using 40 nylon (Nylon monofilament - Point Suture do Brasil IND. de fios cirúrgicos LTDA.-Fortaleza Ceará - Brasil), it was used for the stitches of the surgical wound.

The platelets-rich plasma (PRP $0.7 \mathrm{ml}$ ) was applied in Gprpl, Gprpls, Gprpm and Gprpms before carpal injury stitches with the aid of the scalpel handle and distributed evenly between the subcutaneous tissue of the donor site and the subcutaneous tissue of the recipient bed, and the beasts of the Gcc, Gccs, Gcm and Gcms received $0.7 \mathrm{ml}$ of saline solution $0,9 \%$. After application of the respective solutions proceeded to the stitches of the surgical wound. The surgical sponges were done from the brushes used for antisepsis, as described in the literature (Zanini, 2004). All groups received postoperative dressing. In the groups that received the treatment with compressive dressing, after the implantation of the graft and application of its solutions, the surgical sponge was used at the end of the suture. Analgesia Protocol was with Tramadol hydrochloride (Tramal - Medley Industria Farmacêutica Ltda - Campinas - São Paulo - Brasil) by subcutaneous with dose of $4 \mathrm{mg} / \mathrm{kg}, 12 \mathrm{~h}$ intervals for 7 days, received antibiotic therapy with pentabiotic (Mogipen Jofadel Indústia Farmacêutica S/A Monte Mor São Paulo - Brasil) by subcutaneous with a dose of $0,06 \mathrm{ml} / \mathrm{kg}$ at 48 hour intervals for new dose for 5 days, and anti-inflammatory meloxicam (Maxicam - OuroFino Agronegócios - Cravinhos - São Paulo - Brasil) for 3 days, by subcutaneous with dose of $0.2 \mathrm{mg} / \mathrm{kg}$ on the first day and the second and third day $0.1 \mathrm{mg} / \mathrm{kg}$ at 24 hour intervals.

In all animals of both groups, the dressings were performed in the immediate postoperative period and exchanged on the 3rd, 7th and 15th days, together with the macroscopic evaluations until the date of euthanasia.

Macroscopic assessments of wounds evaluated for the exudate, color, edema, and cosmetic appearance of the wound. The exudate was evaluated in: nonexistent, 1 discrete, 2 moderate and 3 intense. The integrity of the skin consisted in graduating its coloration, ranging from 0 to 3 , where 0 was pallid, 1 pink skin, 2 hyperemic, and 3 cyanotic. Edema was evaluated on a scale of 0 absent, 1 discrete, 2 moderate and 3 intense. Evaluation of the cosmetic aspect used graduation of 0 excellent, 1 good, 2 regular and 3 bad.

On the 15 th day after surgery, the animals were euthanized for microscopic evaluation of material harvest. The material was referred to Veterinary Pathology Laboratory at the University of Porto, Portugal, for making the slide for microscopic evaluation.

The samples were processed by conventional routine histological processing, embedded in paraffin blocks, and performance of histological sections. These were cut on a microtome with a thickness of 2 micrometers in a sequence; hydration was carried out at increasing dilutions of alcohols and diaphanization in xylol. The histological analysis was performed by the same pathologist (FG) without prior knowledge of identification of groups. Histological evaluation of tissue was examined under an optical microscope at 400x magnification. The photomicrographs were held at NIS program Nikon Imaging Software Elements version 30.4 NIS program - Nikon Imaging Software Elements version 4.30. Hematoxylin \& Eosin was used for evaluation of epidermis and dermis for the presence of necrosis, mononuclear cells, polymorphonucleate, fibroblast proliferation and hemorrhage; Hematoxylin \& Eosin and Masson's Trichromic (blue contrast) for vascular proliferation; Picrosirius (Easy Path - Sirius Red Staining) for evaluation collagenous.

The data obtained was determined by the semiquantitative and quantitative method of as recommended to the literature (Garros et al., 2006). Only for the data of the PicroSirius, sections were analyzed by optical microscopy under polarized light (Olympus BX-53 §, Japan). The observation of the collagen fibers through this method allowed the differentiation of type I collagen (birefringence yellowishorange to orange and red) and type III (green or yellow-green birefringence) (Coleman, 2011). Of each slide were selected and photomicrographed ten histological fields with a digital camera $(5.0 \mathrm{~m})$ in increased $20 \mathrm{x}$. The images were 
analyzed with the aid of software Image $\mathrm{J} 囚$, with the plug-in Colour Threshold, obtaining the percentage of collagen by analysis of automated particle according to selection and extent of areas based on color as described in the literature (Bedoya et al., 2016).

For the immunohistochemical study, a panel of antibodies specific for several antigens was applied (Table 1). The glass slides was previously cleaned and degreased, prepared with prepared with organosilane-based adhesive (3aminopropyl triethoxysilane, C.O. Sigma Chemical, USA). Novolink ${ }^{\mathrm{tm}}$ Polymer Detection Systems was used according to the manufacturer's instructions.

Table 1. Antibodies used for immunohistochemistry cutaneous tissues of rabbits conducted in Veterinary Pathology Laboratory of the University of Porto, Portugal, in 2016

\begin{tabular}{cccccccc}
\hline Marker & Clone & Supplier & Diluition & $\begin{array}{c}\text { Antigenic } \\
\text { recovery }\end{array}$ & $\begin{array}{c}\text { Incubation } \\
\text { period }\end{array}$ & $\begin{array}{c}\text { Detection } \\
\text { system }\end{array}$ & $\begin{array}{c}\text { Positive } \\
\text { control }\end{array}$ \\
\hline Ae1/Ae3 & $\begin{array}{c}\text { Monoclon } \\
\text { al,Ae1/Ae } \\
3\end{array}$ & $\begin{array}{c}\text { ImPath, } \\
\text { USA }\end{array}$ & $1: 400$ & $\begin{array}{c}\text { Retrieval } \\
\text { solution, } \\
\text { Novocastra }\end{array}$ & $\begin{array}{c}\text { Overnight } \\
4^{\circ}\end{array}$ & $\begin{array}{c}\text { Vectastain } \\
\text { elite ABC } \\
\text { Kit }\end{array}$ & $\begin{array}{c}\text { Rabbit } \\
\text { normal } \\
\text { skin }\end{array}$ \\
$\begin{array}{c}\text { Caveolin } \\
\text { e-1 }\end{array}$ & $\begin{array}{c}\text { Polyclonal } \\
\text { anti- } \\
\text { caveoline }\end{array}$ & $\begin{array}{c}\text { BD } \\
\text { Pharming } \\
\text { en }\end{array}$ & $1: 500$ & - & 45 minutes & $\begin{array}{c}\text { Polymer } \\
\text { Detection } \\
\text { Rabbit } \\
\text { normal } \\
\text { skin }\end{array}$ \\
\hline
\end{tabular}

The data obtained from the Ae1/Ae3 were evaluated in photomicrographs obtained by an optical microscope, increased $2 \mathrm{x}$, made NIS program - Nikon Elements Imaging Software version 4.30. Subsequently, the images were analyzed using the software Image $\mathrm{J} \AA$, with the plug-in Colour Threshold to yield the percentage of the total area of reepithelialization of the wound using the automated particle analysis according to the selection and measurement areas based on the color (Gobi, 2013).

The angiogenic index for Caveolin-1 was determined by microvessel counting technique according to Maeda et al. (1995). The microvessel count was determined twice by a single rater, at two different times and was expressed as mean number of vessels in each case studied.

The comparison between groups (Gprpl, Gprpls, Gcl, Gcls, Gprpm, Gprpms, Gcm, Gcms) in relation to the categorical variables (exudate, edema, color, cosmetic appearance, vascular proliferation, mononuclear cells, polymorphonuclear cells, fibroblast proliferation, hemorrhage and necrosis) was performed by Kruskal-Wallis test, with subsequent use of the multiple comparison test of Dunn, for cases in which there was significant difference between the medians of the groups. In all tests, $p$ values equal or less than $0.05(\mathrm{P}<0.05)$ was considered significant. For the analysis was used Npar1way procedure computer program SAS (Satistical..., 2002) and the GraphPad Prism program, Version 4.00 .

The epithelialization data, and collagen of different types of collagen fibers, according to the degree of differentiation were compared by analysis of variance ( $F$ test) for a completely randomized design with eight groups and ten repetitions per group, considering $\mathrm{p}$ values equal or less than $0.05(\mathrm{P}<0.05)$ significant. The evaluation data immunohistochemistry using Caveolin-1 were also subjected to analysis of variance, with eight groups (Gprpl, Gprpls, Gcl, Gcls, Gprpm, Gprpms, Gcm, Gcms) and five repetitions (average) per group and level of significance of $5 \%$. In both cases, there was a significant difference between means $(\mathrm{P}<0.05)$, these were compared by Tukey test at the level of significance $(5 \%)$. For this analysis, we used the General Linear Models Procedure (GLM) of the SAS computer software (Satistical..., 2002).

\section{RESULTS AND DISCUSSION}

Edema and exudate with $3(\mathrm{P}=0,03)$ and 7 days $(\mathrm{P}=0.0049)$ (Figure 1); coloring on the 14th day $(\mathrm{P}=0.0001)$; cosmetic appearance on the $7^{\text {th }}(\mathrm{P}=$ $0.0026)$ and 14 th day $(\mathrm{P}=0.0001)$ were significant. 


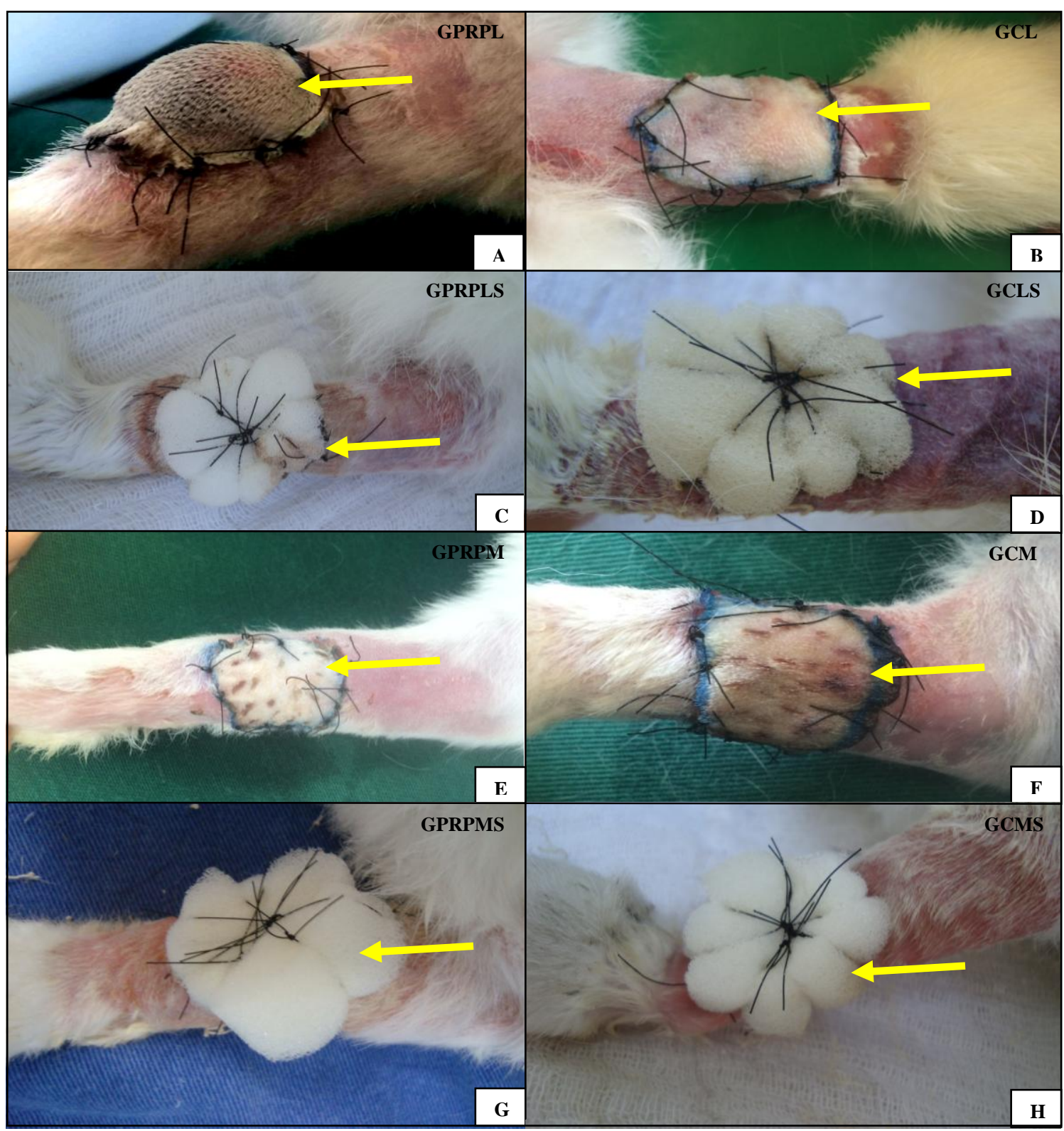

Figure 1. Photographic images of the lesion in the left forelimb in carpal region of rabbits having macroscopic variables edema with three days that were significant between groups $(\mathrm{P}<0.05)$ submitted to the reconstructive surgery procedure at the Veterinary Hospital Faculty of Agricultural and Veterinary Sciences (FCAV) of Unesp, Jaboticabal Campus, 2015.A) edema presence in the Gprpl (arrow). B) No edema in Gcl (arrow). C) Exsudate presence in the Gprpls (Arrow), no edema. D) No edema and exsudate in the Gcls. E, F,G, H) No edema and exsudate in the Gprpm and Gcm, Gprpms, Gcms (Arrow).

The results obtained in this study on the macroscopic variable presence of edema was significant between groups ranging from discreet to intense in Gprpl and Gcls 3 and 7 days of surgery respectively, and the results similar to Bauer et al. (2009), which evaluated the effects of platelet-rich plasma in the dermal wound repair process in rats and found 24 hours after surgical procedure intense edema in the treated and control group. But another important issue evaluated was the use of surgical sponges associated with PRP, then this work is in agreement with the results of Zanini et al. (2004) who used surgical sponge as a pressure dressing 
for skin grafts in the face of human, and found favorable results with their research, presenting itself as ideal dressing, It promotes ventilation, exudate absorption and reduction of edema, recommending the application sponge as a pressure dressing mode. Given the results, surgical sponges can be inferred to favor reducing post-surgical edema, although there were surgery mild edema in the Gccs animals with seven days, the use of the of sponges is justified by improving healing. Regarding the exudate, such change was significant in some of the groups we used the PRP, appearing in Gprpms and Gprpm during the 3rd and 7th post operative respectively. The results of this testing are contrary to Pazzini et al. (2016a), who used the PRP in Thoracodorsal axial pattern flaps in rabbits and observed a significant presence of exsudate in animals that did not receive the product.

As for color, cyanotic color was present in Gprpm and Gprpl, this fact can be correlated with the presence of hemorrhagic areas from the anastomosis of neovascularization. Pink color in Gprpms and Gprpls indicated the integrity of grafts. Thus the results suggest that the use of surgical sponges PRP was associated with favorable healing of the grafts. This finding is not consistent with Vendramin et al. (2010a), who reported the use of PRP in skin grafts in pelvic limb human being capable of reducing the size of the lesion by promoting the larger amount of granulation tissue and presenting a pinkish appearance of the skin when compared with patients not receiving the product. Thus, it can be assumed that the use of PRP with a combination of surgical sponges resulted in better color since the use of surgical sponges promoted adequate pressure on the wound and attached to the PRP promoted healing.

Regarding the cosmetic appearance of the wound, it was found that variable in Gprpls and Gprpms ranging from excellent to good, with such features can be inferred that the use of PRP associated with surgical sponges is favorable to the healing of the grafts. At the end of 15 days was found graft integration in receptor bed, so the pressure of the sponges and angiogenesis stimulating factors present in the PRP are capable to replacing the granulation tissue and promote proper healing of the grafts. The results of this trial are consistent with Vendramin et al. (2010b), who used the platelet rich plasma autologous skin grafts in rabbits, and there were favorable results in wound healing. Regarding the use of surgical sponges, the results obtained in this study corroborate Zanini et al. (2004), who used a surgical sponge as a pressure dressing for skin grafts in humans, and obtained favorable results in respect of healing, and indicate and advise the use of surgical sponges in skin grafts.

Histological evaluation of the intensity and quantification of vascular proliferation evaluated by histochemical method Hematoxylin \& Eosin (HE) and Masson's was found that this variable was significant in Gprpms $(\mathrm{P}=0.01)$ (Figure 2A) when compared with the Gprpl (Figure 2B) and Gcms (Figure 2C), mean vessel 55; 33 and 14 shown respectively in groups. In Gprpm proliferation of vessels was compared with Gprpl significant $(\mathrm{P}=0.01)$ and $\mathrm{Gcms}(\mathrm{P}=0.01)$ with a mean of 32.3 vessel; 34 and 14.6 respectively in our groups, and among the other groups there was no significant difference $(\mathrm{P}>0.05)$.

Comparing the semi-quantitative and quantitative evaluation methods there were no significant difference between the two methods $(\mathrm{P}=0.3)$. However, the quantitative analysis's more reliable, and as the histochemical method, Masson's Trichromic is better to visualizate the vessels compared to HE.

When angiogenesis in the wound was evaluated using Caveolin-1, it a significant presence of vascular proliferation was found $(\mathrm{P}=0.001)$. The microvessel count of the of the wound using Caveolin-1 was significant at Gprpms $(\mathrm{P}=0.001)$ (Figure 3A), compared with the Gprpl (Figure 3B) and $\mathrm{Gcms}$ (Figure 3C), averaging 56.5 vessels; 33.5 and 15.3 respectively appear in groups. In Gprpm vascular proliferation was significant $(\mathrm{P}=0.002)$ compared with $\mathrm{Gprpl}$ and Gcms, with an average of 38.6 vessels; 33.5 and 15.3 respectively in our groups, and among the other groups there was no significant difference $(\mathrm{P}=0.3)$ 


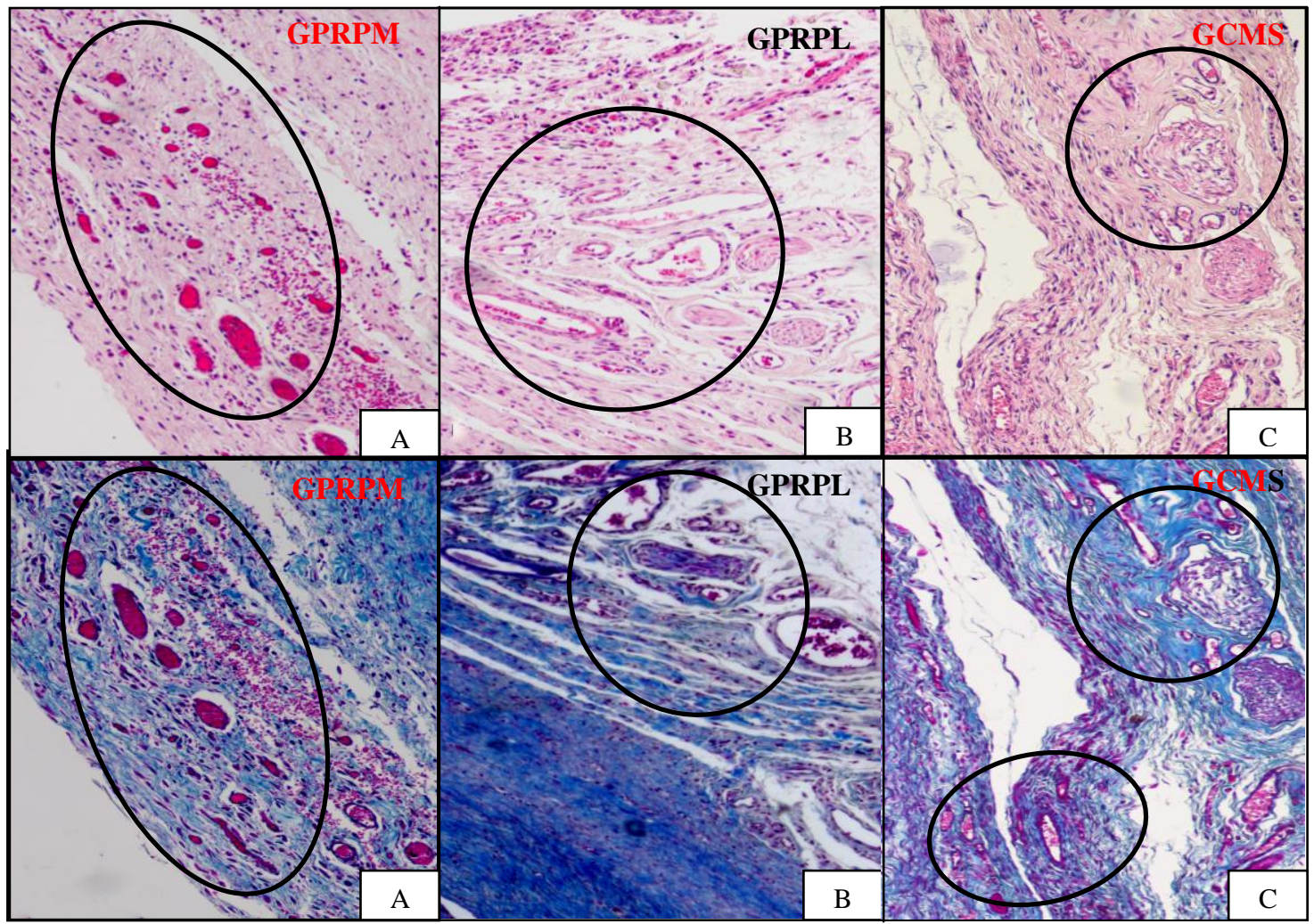

Figure 2. Histology of vascular proliferation intensity in rabbits (Oryctolagus cuniculus). Photomicrography optical dermal animals underwent reconstructive surgery procedure at the Veterinary Hospital of the Faculty of Agricultural and Veterinary Sciences (FCAV) of Unesp, Jaboticabal Campus, 2015. A) Marked presence of neovascularization in circumscribed area in Gprpms. B) Presence of neovascularization circumscribed region in Gprpl. C) Discret presence of neovascularization in circumscribed area in Gcms. 100X. HE staining and Masson's trichrome respectively.

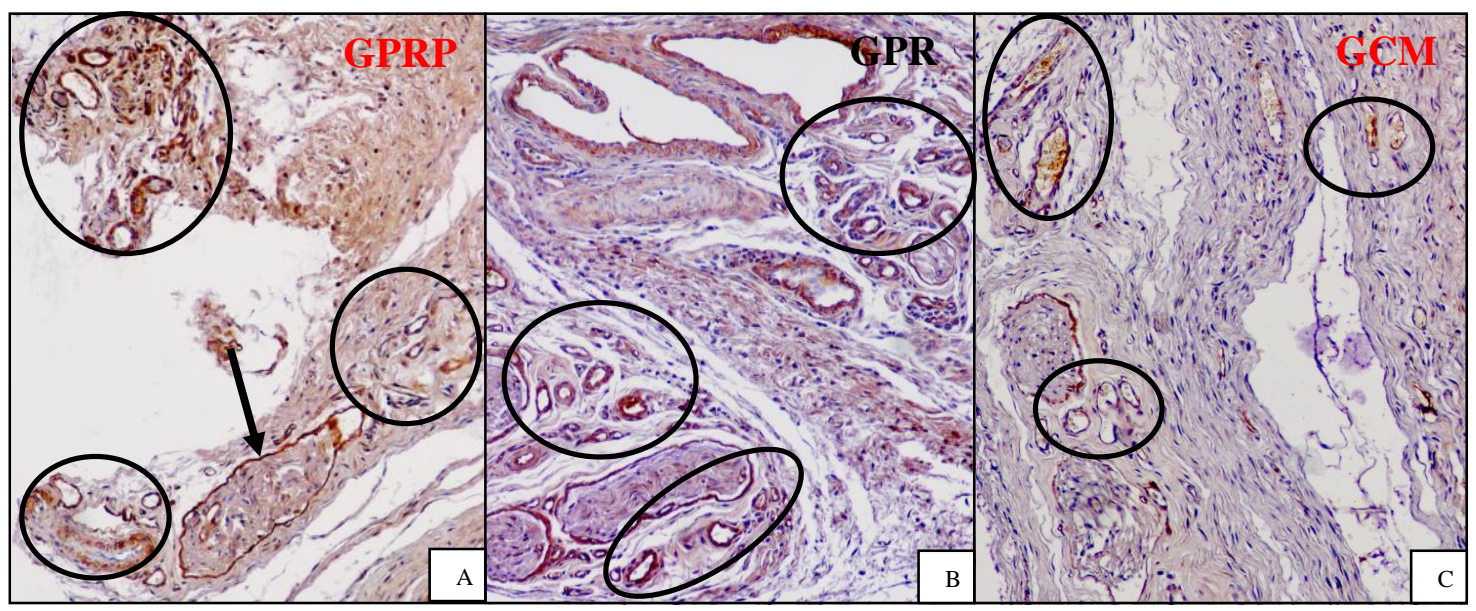

Figure 3. Histology of vascular proliferation in rabbits (Oryctolagus cuniculus). Photomicrography optical dermal animals underwent reconstructive surgery procedure at the Veterinary Hospital of the Faculty of Agricultural and Veterinary Sciences (FCAV) of Unesp, Jaboticabal Campus, 2015. A) Presence marked neovascularization in circumscribed area in Gprpms, noting the presence of nerve skin (arrow). B) Presence of neovascularization circumscribed region in Gprpl. C) Discreet presence of neovascularization in circumscribed area in Gcms. 100X. Marker Caveolin-1. 
The use of platelets plasma rich in the subcutaneous recipient bed wound has provided good results in the Gprpms and Gprpm when compared with other groups that were receiving PRP and saline solution so that the difference found as the vascular proliferation is related to the use of PRP as well as the type of graft employed. Therefore, it can be inferred that this compound is efficient promoting angiogenesis at the site of application and stimulating granulation tissue formation due to its growth factors this was observed under the receptor bed that it does not having present the prior presence of granulation tissue before use of the graft, and applying the PRP was good to integration of the graft in the recipient bed as described in the literature (Huppes et al., 2015). This is research emphasizing that the model of the surgical technique may be related to the success of healing, and this test proved that use of surgical sponges associated with PRP favored the integration of grafts in the recipient bed, comparing the models grafts used can infer the mesh graft exhibit better characteristics compared to the layered, these results are consistent with Pazzini et al. (2015), describing the model mesh as good as compared layer, since this is easier to expand on the receptor, promote drainage of secretions and shows survival rate 90 to $100 \%$.

As to the wound inflammatory response, the presence of mononuclear cells and polymorphonuclear cells among experimental groups, the presence of mononuclear $\mathrm{Gcms}$ significant $(\mathrm{P}=0.01)$ when compared with Gprpms, and showing no difference between the groups. The presence of polymorphonuclear was significant when compared to the Gcms Gprpl and $\operatorname{Gprpm}(\mathrm{P}=0.01)$, but significant when compared to the Gcl and Gprpl Gprpm $(\mathrm{P}=0.01)$, indicating the presence of inflammatory reaction resulting from the healing process. The results found in this study are contrary to Vendramin et al. (2010b), who used the PRP skin grafts in rabbits and there were significant differences between treated groups and the control for the presence of inflammatory cells associated with the use of the product with increased inflammatory response and yet have obtaining good results with the use of the product.

Also, they are contrary to those achieved by Pazzini et al. (2016a), which used platelet-rich plasma in a thoracodorsal flap axial pattern in rabbits and finding no significant difference in the presence of inflammatory cells between the treated and control groups.

An intense fibroblast roliferation was foung in the Gprpc and Gprpm significant presence compared with $\mathrm{Gcms}(\mathrm{P}=0.01)$ but had no difference with the other groups. The great proliferation of fibroblasts may be related to the use of PRP, increasing fibroblast proliferation rate and extracellular matrix synthesis improving the general repairs, however, it was expected that this fact would be present in all groups that received PRP, not only into two groups. The results of this assay for the proliferation of fibroblasts shows that the fibroblasts proliferation is intensive in some groups that used the PRP, in agreement Vendramin et al. (2010b), who used the PRP in autologous skin grafts in rabbits and found a higher concentration of fibroblasts and macrophages was used as PRP. According to Bhanot et al. (2002) also reported that PRP increases collagen production, angiogenesis, fibroblast proliferation and extracellular matrix synthesis improving wound healing in general.

As for collagenous evaluating collagen type I and III had a significant difference between groups $(\mathrm{P}<0.05)$. Collagen type I and III shows a significant difference when compared with each other, and important type I in Gprpms compared to $\mathrm{Gcl}(\mathrm{P}=0.05)$, this fact can be attributed to the application of PRP, as their implementation significantly improves wound healing, considering the slip model with surgical sponge. When evaluated were, the collagen fibers type III there was no significant difference between groups. This assay shows a significant presence of type I collagen in Gprpms animals when compared with $\mathrm{Gcl}$, indicate that the scar properly progresses through the stages of healing afther 15 days there was had mature collagen and tensile strength of the wound. This fact can be justified by the use of PRP, which can stimulate mesenchymal and epithelial cells to migrate to the injured site, resulting in a mitotic division, and ultimately stimulating the matrix synthesis and collagen, resulting in a faster and efficient healing (Marx, 2004).

Microscopic findings indicated the slight presence of hemorrhage in all groups, but sometimes more severe in animals that employed 
PRP gel. However, it was found the presence of significant hemorrhage in Gcms $(P=0,007)$ compared with Gprpms. The presence hemorrhage in Gcms animals indicates to be a case in point, given that using the PRP is the formation of new small and medium vessels caliber, wich can easily "break up" for being fragile, resulting in the presence of local hemorrhage (Pazzini et al., 2016a). Furthermore, the use of surgical sponges is also necessary to avoid the presence of the hemorrhage in the wound (Zanini et al., 2004). Although there was a presence of hemorrhage in association surgical sponge, its use is also advisable, as they occur 15 days after surgery is directly related to the use of PRP and angiogenesis, not to the fact of postsurgical bleeding. The intensity of reepithelialization and necrosis between groups was not significantly different $(\mathrm{P}=0,1$ and $\mathrm{P}=$ 0.2928).

\section{CONCLUSIONS}

The results of this study evidenced that the use of platelet-rich plasma in skin grafts associating postoperative surgical sponge as a pressure dressing improves its integration into the recipient bed without the prior presence of granulation tissue. PRP can stimulate new vessels promote the repair phase and integration of the graft in the recipient bed, but when applied without the association of surgical sponges, the results indicated that their use alone is not favorable. Comparison between the graft models into mesh and layer associated with PRP, as well as surgical sponges, indicated that the best graft model is mesh type, which can be associated with PRP and surgical sponge to achieve better effects.

\section{REFERÊNCIAS}

BAUER, J.A.; CORREA, J.; LIMA, M.F.L.; LIMA, L.A.P.A.; PUSTIGLIONI, F.E. Efeitos do plasma rico em plaquetas no processo de reparação de feridas dérmicas padronizadas em ratos. Rev. Periodontal., v.19, p.98-108, 2009.

BEDOYA, S.A.O; CONCEIÇÃO, L.G.; VILORIA, M.I.V. et al. Caracterização de colágenos tipos I e III no estroma do carcinoma de células escamosas cutâneo em cães. Arq. Bras. Med. Vet. Zootec., v.68, p.147-154, 2016.
BHANOT, S.; ALEX J.C. Current applications of platelet gels in facial plastic surgery. Facial Plast. Surg., v.18, p.27-33, 2002.

CASTRO, J.L.C.; HUPPES R.R.; DE NARDI, A.B.; PAZZINI J.M. Princípios e técnicas de cirurgias reconstrutivas da pele de cães e gatos (atlas colorido). In. CASTRO, J.L.C.; HUPPES, R.R.; DE NARDI, A.B.; PAZZINI, J.M. Introdução à anatomia. Curitiba: Medvep, 2015. Cap.1, p.10-16.

COLEMAN, R. Picrosirius red staining revisited. Acta Histochem., v.113, p.231-233, 2011.

GARROS, I.C.; CAMPOS, A.C.L.; TÂMBARA, E.M. Extrato de Passiflora edulis na cicatrização de feridas cutâneas abertas em ratos: estudo morfológico e histológico. Acta Cir. Bras., v.21, Supl.3, p.55-65, 2006.

GOBI, G.L.M. Análise cicatricial de úlceras por pressão utilizando o óleo de coco ozinizado. 2013. 99f. Dissertação (Mestrado) Universidade Camilo Castelo Branco, São José dos Campos, São Paulo, SP.

HUPPES, R.R.; CARNEIRO, S.C.M.C.; DANTAS, A.V.E. et al. Enxertos cutâneos em cães com diferentes preparos no leito receptor relato de caso. Medvep Rev. Cient. Med. Vet., v.13, p.22-28, 2015.

MAEDA, S.; CHUNG, Y.S.; TAKATSUKA, S. et al. et al. Tumor angiogenesis and tumour cell proliferation as prognostic indicador in gastric carcinoma. Br. J. Cancer, v.72, p.319-323, 1995.

MARX, R.E. Platelet-rich plasma: evidence to support its use. J. Oral Maxillofac. Surg., v.62, p.489-96, 2004.

PAVLETIC, M.M. Small animal wound magementand reconstructive surgery: In:

Free grafts. 3.ed. Iowa: Wiley Blackwell, 2010. cap.14, p.404-431.

PAZZINI, J.M.; DE NARDI, A.B.; HUPPES, R.R. et al. Method to obtain platelet rich plasma from rabbits (Oryctolagus cuniculus). Pesqui. Vet. Bras., v.36, p.39-44, 2016b.

PAZZINI, J.M.; DE NARDI, A.B.; HUPPES, R.R. et al. Utilização de plasma rico em plaquetas para estimulação da angiogênese em flape de padrão axial toracordosal em coelhos (Oryctolagus cuniculus). Pesqui. Vet. Bras., v.36, p.108-118, 2016a. 
PAZZINI, J.M.; MORAES, P.C. Princípios e técnicas de cirurgias reconstrutivas da pele de cães e gatos (atlas colorido). Curitiba: Medvep, 2015. p.95-102.

SANTOS, L.A.U. Efeitos da utilização do plasma rico em plaquetas na osteointegração dos enxertos ósseos criopreservados: estudo histomorfométrico em coelhos. 2007. 140f. Dissertação (Mestrado em Ciências) Universidade de São Paulo, São Paulo, SP.

STATISTICAL analysis system. Version 9.1. Cary: SAS Institute, 2002.
VENDRAMIN, F.S.; FRANCO, D.; FRANCO, T.R. Utilização do plasma rico em plaquetas (PRP) autólogo em enxertos cutâneos em coelho. Rev. Col. Bras. Cir., v.25, p.4-10, 2010 b.

VENDRAMIN, F.S.; FRANCO, D.; SCHAMALL, R.F.; FRANCO, T.R. Utilização do plasma rico em plaquetas autólogo em nas cirurgias de enxertos cutâneos em feridas crônicas. Rev. Col. Bras. Cir., v.25, p.589-594, 2010a.

ZANINI, M.; MACHADO FILHO, C.A.S.; TIMONER, F. Uso de esponja cirúrgica para curativo compressivo de enxerto cutâneo. An. Bras. Dermatol., v.79, p.3569-362, 2004. 